OPEN ACCESS

Edited by

Rene De Waal Malefyt, Merck Research Laboratories,

United States

Reviewed by:

Daniel Olive,

Institut National de la Santé et de la Recherche Médicale (INSERM), France

Wendy L. Havran,

Scripps Research Institute,

United States

*Correspondence:

Marie-Caroline Dieu-Nosjean

mc.dieu-nosjean@crc.jussieu.fr

Specialty section:

This article was submitted

to T Cell Biology,

a section of the journal

Frontiers in Immunology

Received: 02 May 2017

Accepted: 16 June 2017

Published: 30 June 2017

Citation:

Lawand M, Déchanet-Merville J and

Dieu-Nosjean M-C (2017) Key Features of Gamma-Delta T-Cell

Subsets in Human Diseases and

Their Immunotherapeutic

Implications.

Front. Immunol. 8:761.

doi: 10.3389/fimmu.2017.00761

\section{Key Features of Gamma-Delta T-Cell Subsets in Human Diseases and Their Immunotherapeutic Implications}

\author{
Myriam Lawand ${ }^{1,2,3}$, Julie Déchanet-Merville ${ }^{4}$ and Marie-Caroline Dieu-Nosjean ${ }^{1,2,3 *}$ \\ ${ }^{1}$ Cordeliers Research Center, UMRS 1138, Team "Cancer, Immune Control and Escape", INSERM, Paris, France, ${ }^{2}$ Cordeliers \\ Research Center, UMRS 1138, University Sorbonne-Paris Cité, University Paris Descartes, Paris, France, ${ }^{3}$ Cordeliers \\ Research Center, UMRS 1138, University Pierre and Marie Curie (UPMC), Paris 06, University Paris-Sorbonne, Paris, \\ France, 4 ImmunoConcEpT, CNRS UMR 5164, University of Bordeaux, Bordeaux, France
}

The unique features of gamma-delta $(\gamma \delta)$ T cells, related to their antigen recognition capacity, their tissue tropism, and their cytotoxic function, make these cells ideal candidates that could be targeted to induce durable immunity in the context of different pathologies. In this review, we focus on the main characteristics of human $\gamma \delta$ T-cell subsets in diseases and the key mechanisms that could be explored to target these cells.

Keywords: human gamma-delta T cell, cytotoxicity, cytokine, NK receptor, antigen presentation, cancer, infection, autoimmunity

\section{INTRODUCTION}

Gamma-delta $(\gamma \delta)$ T cells are an important subset of "unconventional" T lymphocytes as they have the ability to recognize a broad range of antigens without the presence of major histocompatibility complex (MHC) molecules. They can attack target cells directly through their cytotoxic activity or indirectly through the activation of other immune cells. $\gamma \delta$ T-cell functional responses are induced upon the recognition of stress antigens, which promotes cytokine production and regulates pathogen clearance, inflammation, and tissue homeostasis in response to stress (1).

However, given that different parameters concerning human $\gamma \delta$ T-cell function and phenotype within tissues are still not well understood, it is important to be updated on the current state of knowledge of human $\gamma \delta$ T cells. This will permit a better understanding of what could be performed in the future and how to target them in order to improve the management of patients.

For this aim, this review describes the main features of human $\gamma \delta$ T-cell subsets in various pathologies and discusses the mechanisms by which they influence the outcome of the immune response that could be targeted for immunotherapy.

\section{PLEIOTROPIC ROLE OF HUMAN $\gamma \delta$ T CELL SUBSETS}

In humans, there are two major subsets of $\gamma \delta \mathrm{T}$ cells identified by their V $\delta$ chain. V $\delta 1 \mathrm{~T}$ cells are predominant in the thymus and peripheral tissues and recognize various stress-related antigens mostly uncharacterized. V82 T cells constitute the majority of blood $\gamma \delta \mathrm{T}$ cells (2). They always associate to the $\mathrm{V} \gamma 9$ chain in adults and mainly recognize phosphoantigens, i.e., phosphorylated non-peptidic molecules that are metabolic intermediates of the isoprenoid biosynthesis (3).

\section{Major Cytokines and Cytotoxic Potential}

Both human $\gamma \delta$ T-cell subsets exhibit a cytotoxic potential that is induced through the expression of cell surface receptors [i.e., $\gamma \delta$ TCR (T-cell receptor) and NKG2D (natural killer group 2D)] and is preponderantly mediated by the release of soluble mediators (i.e., perforin and granzymes) $(4,5)$. They 
can produce granulysin, which is a potent anti-microbial protein $(6,7)$, and express ligands such as CD95L and Tumor necrosis factor-related apoptosis-inducing ligand, which engage several death receptors on target cells. In addition, they can kill their targets indirectly through antibody-dependent cellular cytotoxicity (ADCC) in a CD16-dependent mechanism (8). Other molecules such as DNAM-1 (DNAX accessory molecule-1), leukocyte function-associated antigen-1, and the co-stimulatory receptor CD27 are also involved in $\gamma \delta$ T-cell activation and cytotoxicity (9).

Importantly, cord blood naïve $\gamma \delta$ T cells can differentiate into the IL-17+IFN- $\gamma^{-}$V $\gamma 9$ V $\delta 2$ T cells with a cytotoxic potential in the presence of IL-23 and a TCR signaling (10). In contrast, thymic naïve $\gamma \delta$ T cells secrete IFN- $\gamma$ in the presence of IL- 2 or IL-15, through the de novo expression of T-bet and eomesodermin, and the release of cytotoxic molecules against leukemia cells (11). Other studies reported IL- $17^{+} \gamma \delta$ T-lymphocyte differentiation in the presence of IL-7 (12) or other activation stimuli (13) and high inflammatory conditions $(14,15)$.

Altogether, human $\gamma \delta \mathrm{T}$ cells represent key actors of the immunity because of their pro-inflammatory phenotype and cytotoxic potential.

\section{Antigen Presentation Capacity}

Human $\gamma \delta \mathrm{T}$ cells can exhibit an antigen-presenting capacity. Similar to dendritic cells (DCs), blood V $\gamma 9 \mathrm{~V} \delta 2 \mathrm{~T}$ cells are able to respond to signals from microbes and tumors and prime $\mathrm{CD}^{+}$ and $\mathrm{CD}^{+} \mathrm{T}$ cells (16). Indeed, $\gamma \delta \mathrm{T}$-APCs were also described to cross-present antigens to $\mathrm{CD}^{+} \mathrm{T}$ cells (17). The intracellular protein degradation and endosomal acidification are significantly delayed in $\gamma \delta \mathrm{T}$ cells in comparison to monocyte-derived DCs (18). The antigens are transported across IRAP (InsulinRegulated AminoPeptidase)-positive early and late endosomes (19), and their processing consists of an export to the cytosol for degradation by the proteasome before being imported into a MHC-I-loading compartment (18). Moreover, activated $\gamma \delta$ $\mathrm{T}$ cells are able to phagocytose tumor antigens and apoptotic or live cancer cells possibly through the scavenger receptor CD36 in a $\mathrm{C} / \mathrm{EBP} \alpha(\mathrm{CCAAT} /$ enhancer-binding protein $\alpha)$-dependent mechanism and mount a tumor antigen-specific $\mathrm{CD}^{+}{ }^{+} \mathrm{T}$-cell response (20). Moreover, $\gamma \delta \mathrm{T}$ cells can induce DC maturation through TNF- $\alpha$ production $(21,22)$.

Overall, $\gamma \delta \mathrm{T}$ cells can process a wide range of antigens for presentation and stimulate other immune cells. Therefore, their implication in response to infections or cancer would help to design new strategies in order to improve clinical response of human $\gamma \delta$ T cell-based immunotherapy.

\section{Key Receptors in Immune Surveillance}

Different receptors namely the TCR, co-stimulatory molecules, and NK receptors play a key role in the regulation of $\gamma \delta$ T-cellmediated immune responses [reviewed in Ref. (23)]. For instance, the activation of blood $\mathrm{V} \gamma 9 \mathrm{~V} \delta 2 \mathrm{~T}$ cells by anti-NKG2D antibody or its ligand MICA (MHC class I chain-related sequence A) induces TNF- $\alpha$ production and the release of cytolytic granules (24). Moreover, the triggering of NKG2D enhanced their response to microbe-associated antigens (25). In lymphocytic leukemia, a hematologic tumor highly resistant to activated Vy9V8 $2 \mathrm{~T}$ cells,
IL-2 or IL-15, and TCR stimulation upregulates the expression of NK receptors NKp44, NKp46, and NKp30 on $\mathrm{V} \delta 1^{+} \mathrm{T}$ cells, allowing their acquisition of cytotoxicity against leukemia cells (26). DNAM-1 engagement can also promote the activation of V82 T cells and ultimately, the killing of tumor cells $(27,28)$. Phosphoantigen stimulation of $\mathrm{V} \gamma 9 \mathrm{~V} \delta 2 \mathrm{~T}$ cells is able to induce TNF- $\alpha$ production through the upregulation of CD16 expression (29). Its role in mediating ADCC was highlighted using therapeutic antibodies such as anti-CD20 (Rituximab) (30) and anti-HER2 antibody (Trastuzumab) (31).

The CD27-CD70 axis can enhance phosphoantigendependent activation, survival, proliferation, and secretion of pro-inflammatory cytokines of $\mathrm{V} \gamma 9 \mathrm{~V} \delta 2 \mathrm{~T}$ cells (32). These results suggest that CD27 can modulate V $82 \mathrm{~T}$-cell activation and hence seems to be a major tool that could be manipulated in clinical settings. Of note, CD27 is expressed on $\mathrm{V} \delta 1^{+}$cells and, thus, may also play a role in their effector functions (32).

The promotion of a robust NK cell-mediated antitumor cytotoxicity has also been described through CD137 (4-1BB) engagement on blood activated $\gamma \delta$ T lymphocytes which in turn induces the upregulation of NKG2D by NK cells, followed by the eradication of tumor cells (33).

In contrast, regulatory receptors for self-MHC class I molecules, particularly KIR (Killer cell Immunoglobulin-like Receptor) and LIR (Leukocyte Immunoglobulin-like Receptor) receptors, were reported to negatively regulate $\gamma \delta$ T-cell activation $(34,35)$. This inhibition is due to the presence of intracytoplasmic ITIM (Immunoreceptor Tyrosine-based Inhibitory Motif) motif in the sequence of these receptors which turn off the activation signals upon phosphorylation. The ligation of BTLA (B- and T-Lymphocyte Attenuator), another regulatory receptor strongly expressed by resting $\mathrm{V} \gamma 9 \mathrm{~V} \delta 2 \mathrm{~T}$ cells, attenuates their own proliferation (36). The engagement of PD-1 (programmed cell death-1) expressed on activated $\gamma \delta \mathrm{T}$ cells downregulates IFN- $\gamma$ production and their cytotoxic function (37).

Understanding the role of these mechanisms in $\gamma \delta \mathrm{T}$ cellimplication in pathological situations needs further investigations that would be important to develop proper strategies targeting these activation and inhibitory receptors. This would ensure an efficient activation of human $\gamma \delta$ T cells in immune surveillance against tumors, pathogens, or autoimmunity and ultimately avoid undesired cytotoxicity against the host through a better discrimination between normal and altered tissues.

\section{HUMAN $\gamma \delta$ T-CELL SUBSETS IN CANCER, INFECTIOUS DISEASES, AND AUTOIMMUNITY}

\section{Pro- and Antitumor Effect of $\gamma \delta \mathrm{T}$-Cell Subsets}

Tumor-infiltrating $\gamma \delta \mathrm{T}$ cells have been demonstrated to be the most favorable prognostic immune population among many cancer types (38), in agreement with their capacity to kill different tumor cells like leukemia, neuroblastoma, and carcinomas (9).

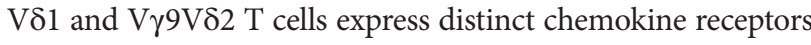
$(39,40)$ and cell adhesion molecules (41) (Table 1), suggesting 
TABLE 1 | Main features of human $\gamma \delta$ T-cell subsets in cancers.

\begin{tabular}{|c|c|c|c|c|}
\hline \multirow[t]{2}{*}{ Pathology } & \multicolumn{3}{|c|}{ Human $\gamma \delta$ T-cell subset features } & \multirow[t]{2}{*}{ Reference } \\
\hline & $\mathbf{V} \delta 1^{+}$ & $\mathbf{V} \delta 2^{+}$ & Other V反2- (non-V $\delta 1)$ & \\
\hline \multirow[t]{10}{*}{ Solid cancers } & $\begin{array}{l}\text { Lysis of the autologous tumor when } \\
\text { extracted from TILs and expanded in vitro in } \\
\text { the presence of IL-2 }\end{array}$ & - & - & (42) \\
\hline & - & $\begin{array}{l}\text { Cytotoxic function, IFN- } \gamma \text { production, and almost } \\
\text { a complete lysis of tumor targets in different } \\
\text { malignancies (after chemotherapy and zoledronate } \\
\text { treatment) }\end{array}$ & - & $(43)$ \\
\hline & & $\begin{array}{l}\text { Expansion and improved cytotoxicity in the } \\
\text { presence of phosphoantigens, amino- } \\
\text { biphosphonates, or a tumor-targeting antibody in } \\
\text { cancer immunotherapy }\end{array}$ & & $\begin{array}{l}\text { Reviewed in } \\
\text { Ref. (44) }\end{array}$ \\
\hline & $\begin{array}{l}\text { CCR5 expression for migration to tumor } \\
\text { sites }\end{array}$ & $\begin{array}{l}\text { CCR5 and CXCR3 expression (consistent with a } \\
\text { Th1-like phenotype) }\end{array}$ & - & (39) \\
\hline & $\begin{array}{l}\text { CCR2 expression for migration to tumor } \\
\text { sites (antitumor effect: production of IFN- } \gamma \\
\text { and cytotoxic function) }\end{array}$ & No CCR2 expression detected & - & $(40)$ \\
\hline & $\begin{array}{l}\text { Expression of various adhesion molecules: } \\
\text { LFA-1, VLA- } \alpha 4 \text { (CD49d), VLA- } \alpha 5 \text { (CD49e), } \\
\text { L-selectin (CD62-L), and } \alpha E \beta 7(C D 103)\end{array}$ & Only LFA-1, L-selectin, and CD44v6 expression & - & $(41)$ \\
\hline & $\begin{array}{l}\text { Ability to kill tumor cells of all melanoma- } \\
\text { isolated V } \delta 1 \text { cell lines }\end{array}$ & $\begin{array}{l}\text { Significant cytotoxic activity for only two out of eight } \\
\text { V } 22 \text { cell lines }\end{array}$ & - & $(45)$ \\
\hline & $\begin{array}{l}\text { Lower susceptibility to activation-induced } \\
\text { cell death, persistence in the circulation for } \\
\text { many years (durable immunity) }\end{array}$ & - & - & $\begin{array}{l}\text { Reviewed in } \\
\text { Ref. (46) }\end{array}$ \\
\hline & $\begin{array}{l}\text { Major cellular source of IL-17 (pro-tumor } \\
\text { role: chronic inflammation in CRC patients) }\end{array}$ & - & - & $(15)$ \\
\hline & $\begin{array}{l}\text { Immunosuppressive and regulatory } \\
\text { properties, such as suppression of dendritic } \\
\text { cell maturation, T-cell proliferation, and IL-2 } \\
\text { secretion }\end{array}$ & - & - & $(47)$ \\
\hline \multirow[t]{4}{*}{$\begin{array}{l}\text { Hematological } \\
\text { malignancies }\end{array}$} & - & $\begin{array}{l}\text { Activation of } \mathrm{V} \gamma 9 \mathrm{~V} \delta 2 \mathrm{~T} \text { cells by zoledronate: } \\
\text { cytotoxicity largely dependent on granule exocytosis } \\
\text { and partly on TRAIL pathways, TCR-mediated, and } \\
\text { dependent on isoprenoid production by leukemia } \\
\text { cells }\end{array}$ & - & $(48)$ \\
\hline & - & $\begin{array}{l}\text { Leukemia/lymphoma cell killing by } \gamma \delta \text { T cells } \\
\text { essentially mediated by ULBP1/NKG2D interaction }\end{array}$ & - & (49) \\
\hline & $\begin{array}{l}\text { Cytotoxicity against lymphoid leukemia cells } \\
\text { associated with the expression of several NK } \\
\text { receptors (mainly NKp30) }\end{array}$ & - & - & (26) \\
\hline & - & - & $\begin{array}{l}\text { Increased percentage of }{\mathrm{V} \delta 2^{-}}^{-} \\
\mathrm{T} \text { cells following CMV infection } \\
\text { in kidney transplant recipients } \\
\text { associated with reduced cancer } \\
\text { risk (among which lymphoma) }\end{array}$ & (50) \\
\hline
\end{tabular}

CMV, cytomegalovirus; CRC, colorectal cancer; LFA-1, leukocyte function-associated antigen-1; NKG2D, natural killer group 2D; TIL, tumor-infiltrating lymphocyte; TRAIL, tumor necrosis factor-related apoptosis-inducing ligand; ULBP1, UL16-binding protein 1; VLA- $\alpha 4$, very late antigen-4.

different homing mechanisms in tumors that can be selectively targeted for immunotherapy. Moreover, isolated V81 lymphocytes from human lung tumors can selectively lyse autologous malignant cells ex vivo (42). Interestingly, administration of Vy9V82 T cells at suitable intervals after chemotherapy and zoledronate treatment increase the cytotoxic function and IFN- $\gamma$ production by $\gamma \delta \mathrm{T}$ cells followed by a complete lysis of tumor cells in different malignancies (43). Different studies also reported the activation of $\gamma \delta \mathrm{T}$ cells after phosphoantigen or aminobiphosphonate injection, an approach which provides promising clinical activity by improving the cytotoxicity of $\gamma \delta$ T cells particularly in presence of tumor-targeting antibody (44). In melanoma, tumor-infiltrating effector-memory $\gamma \delta \mathrm{T}$ cells have been shown to control tumor growth through distinct cytotoxic mechanisms (45) (Table 1). 
Furthermore, V81 T cells wereless susceptible to activation-induced cell death and could persist in the circulation for many years, which is in favor of a durable antitumor immunity (46) (Table 1).

Lamb et al. reported an association between the increased frequency of $\gamma \delta$ T cells and improved disease-free survival of leukemia patients who received $\alpha \beta$ T cell-depleted bone marrow transplants (51). An increased percentage of V $\delta 2^{-} \mathrm{T}$ cells following cytomegalovirus (CMV) infection in kidney transplant recipients was also associated with reduced cancer risk (i.e., lymphoma) (50), suggesting a protective role of $\gamma \delta$ T cells. In the context of chronic myelogenous leukemia (CML), the activation of $\mathrm{V} \gamma 9 \mathrm{~V} \delta 2$ $\mathrm{T}$ cells by zoledronate was shown to increase anti-leukemia activities in a NKG2D-dependent manner, notably in CMLresistant patients (48). Indeed, UL16-binding protein 1 (ULBP1) is involved in lymphoma susceptibility to $\gamma \delta \mathrm{T}$-cell-mediated cytolysis and the blockade of its receptor NKG2D significantly inhibits lymphoma cell killing. Thus, the authors propose that $\gamma \delta \mathrm{T}$ cytotoxic function is achieved through a two-step process (a TCR stimulation presumably by endogenous phophoantigens and a tumor cell recognition by NKG2D) and that ULBP1 could be used as a leukemia/lymphoma biomarker in clinical trials (49). Moreover, since $\mathrm{V} \delta 1^{+} \mathrm{T}$ cells were shown to express several NK receptors that are correlated with a high cytotoxic potential (26), they may constitute a potent therapeutic lymphocyte population that could be targeted for the immunotherapy of lymphocytic leukemia patients that are resistant to activated V $\gamma 9 \mathrm{~V} \delta 2 \mathrm{~T}$ cells.

Nonetheless, a pro-tumor role of $\mathrm{V} \delta 1 \mathrm{~T}$ cells has also been reported. Indeed, in colorectal cancer (CRC), these cells are responsible of the chronic inflammation in CRC patients through IL-17 secretion (15). In addition, some V $\delta 1$ populations could exhibit immunosuppressive properties (i.e., inhibition of DC maturation, suppression of T-cell proliferation and IL-2 secretion), a function that can also be exploited for cancer therapy (47) (Table 1). A high $\gamma \delta$ T-cell infiltrate in breast tumors was positively correlated with advanced tumor stages, HER2 expression status, and lymph node metastasis and ultimately associated with poor outcome of the patients (52). In this study, $\gamma \delta \mathrm{T}$ cells were considered as the most significant independent prognostic factor among many parameters including clinical grade and, thus, may serve as a valuable biomarker and potential therapeutic target for breast cancer.

Altogether, the natural contribution in tumor immunosurveillance and the effector functions of $\mathrm{V} \gamma 9 \mathrm{~V} \delta 2 \mathrm{~T}$ cells represent major advantages that have to be better exploited alone or in combination with current therapies (i.e., phosphoantigens + monoclonal antibodies). However, repeated injection of phosphoantigens may also lead to the anergy or exhaustion of effector $\gamma \delta$ T cells. From an immunotherapeutic standpoint, the rather limited antitumor efficacy of adoptively transferred V $\delta 2$ $\mathrm{T}$ cells and active immunotherapy trials using V $\delta 2$ agonists can be the result of a suboptimal recognition of ex vivo tumor cells, presumably due to insufficient phosphoantigen levels. Therefore, it is now critical to better characterize human $\gamma \delta$ T-cell subsets and the engaged mechanisms in individual cancers, especially the stage of differentiation, the activation status, and the immune checkpoint (ICP)/ICP-ligand expression, to irreversibly convert them toward an antitumor function for efficient immunotherapy.

\section{$\boldsymbol{\gamma} \delta \mathrm{T}$-Cell Subsets in Infections}

$\gamma \delta$ T-cell subsets have been described as potent effector populations against pathogens (Table 2). Indeed, $\mathrm{V} \gamma 9 \mathrm{~V} \delta 2 \mathrm{~T}$ cells can recognize phosphoantigens that are overexpressed in the methyl-erythritol phosphate biochemical pathway (MEP, also called DOXP (1-desoxy-D-xylulose-5-phosphate) pathway), a pathway which is used by many bacteria, fungi and parasites, such as Plasmodium falciparum, Mycobacterium tuberculosis, Toxoplasma gondii, and Listeria monocytogenes [reviewed in Ref. $(53,54)]$. V $\gamma 9 \mathrm{~V} \delta 2 \mathrm{~T}$ cells are thus activated and able to expand in the blood of infected individuals.

During mycobacterial infection, human $\mathrm{V} \gamma 9 \mathrm{~V} \delta 2 \mathrm{~T}$ cells are potently able to inhibit intracellular mycobacteria growth through the secretion of granzyme A and TNF- $\alpha$ (64). In children with bacterial meningitis, an increased percentage of $\mathrm{IL}_{-1} 7^{+} \mathrm{V} \gamma 9 \mathrm{~V} \delta 2$ lymphocytes was detected in the peripheral blood and infected tissues but could be reversed following anti-bacterial therapy (14).

Among $\mathrm{V} \delta 2^{-} \gamma \delta \mathrm{T}$ cells, different clones were demonstrated to be reactive against $\mathrm{CMV}$-infected cells (55), in agreement with their expansion in the blood of CMV-infected patients (57, 68-70) (Table 2). More recently, the V $\gamma 4 \mathrm{~V} \delta 5 \gamma \delta$ T-cell clone isolated from a CMV-infected transplant patient was shown to be reactive against CMV-infected endothelial cells as well as epithelial tumors after binding to the endothelial protein $\mathrm{C}$ receptor (56). In addition, CD16 expression by $\gamma \delta \mathrm{T}$ cells induces IFN- $\gamma$ responses by opsonized CMV virions in a TCR-independent manner and, thus, contributes to the surveillance of CMV reactivation in transplant recipients (8). In a case of severe combined immunodeficiency patient, specific antibody responses to some infectious agents were reported with a predominance of $\mathrm{V} \delta 2^{-} \gamma \delta$ $\mathrm{T}$-cell clones reactive against CMV-infected cells, suggesting functional potentials of $\gamma \delta$ T cells in providing B cell help (57). Therefore, $\gamma \delta$ T cells do not only serve as sentinels in the innate system but can also act as a bridge between innate and adaptive immune responses.

Regarding the V81 T-cell subset, their expansion and activation were also observed in many patients following viral infection such as HCV (hepatitis C virus) $(65,66)$ and HIV $(58,71)$. The specific depletion of V $\delta 2 \mathrm{~T}$ cells is the consequence of the virus infection through gp120-CCR5 interaction $(63,72)$. Nevertheless, uninfected V $\gamma 9 \mathrm{~V} \delta 2$ cells are able to produce large amounts of IFN- $\gamma$, TNF- $\alpha$, and chemokines such as CCL4 and CCL5 [reviewed in Ref. (73)], which bind to CCR4 and CCR5 (the HIV co-receptors), respectively $(74,75)$. Interestingly, in vitro stimulation of $\mathrm{V} \gamma 9 \mathrm{~V} \delta 2$ cells with phosphoantigens induces the release of these chemokines, saturates the co-receptors of HIV, and thus prevents HIV entry and interfere with its replication (76). It also permits the recruitment of more $\mathrm{V} \gamma 9 \mathrm{~V} \delta 2$ cells able to release additional chemokines that would block HIV entry and kill infected cells through direct cytotoxicity or ADCC (62).

Freshly isolated V $\delta 1 \mathrm{~T}$ cells from HIV-infected patients were shown to express CD27, CCR7, and CD161, a molecule involved in $\gamma \delta$ T-cell transendothelial migration and interestingly to proliferate and produce IFN- $\gamma$ and IL-17 in response to Candida albicans ex vivo (59) (Table 2). These observations suggest that V $\delta 1$ lymphocytes might play a major role in the control of HIV infection and in the defense against opportunistic 
TABLE 2 | Main features of human $\gamma \delta$ T-cell subsets in infectious diseases.

\begin{tabular}{|c|c|c|c|c|}
\hline \multirow[t]{2}{*}{ Pathology } & \multicolumn{3}{|c|}{ Human $\gamma \delta$ T-cell subset features } & \multirow[t]{2}{*}{ Reference } \\
\hline & V $\delta 1^{+}$ & V $\delta 2^{+}$ & Other V反2- (non-V反1) & \\
\hline \multirow[t]{4}{*}{ CMV infection } & - & - & $\begin{array}{l}\text { Reactivity of different } \mathrm{V} \delta 2^{-} \gamma \delta \\
\mathrm{T} \text { cell clones against } \mathrm{CMV} \text {-infected } \\
\text { cells }\end{array}$ & $(55)$ \\
\hline & - & - & $\begin{array}{l}\text { Recognition of CMV-targeted } \\
\text { endothelial cells and epithelial } \\
\text { tumors }\left(V_{\gamma} 4 \mathrm{~V} \delta 5 \text { clone interaction }\right. \\
\text { with EPCR) }\end{array}$ & (56) \\
\hline & $\begin{array}{l}\text { Antibody response and reactivity against CMV- } \\
\text { infected cells (in a case of SCID patient) }\end{array}$ & No reactivity reported & $\begin{array}{l}\text { Reactivity against CMV-infected } \\
\text { cells like in the case of V } \delta 1 T \text { cells }\end{array}$ & $(57)$ \\
\hline & $\begin{array}{l}\text { Opsonization of CMV virions through CD16 } \\
\text { (FCyRIIla) expression and induction of IFN- } \gamma \\
\text { responses }\end{array}$ & - & $\begin{array}{l}\text { CD16 (FcyRIIla) expression like } \\
\text { V81 T cells }\end{array}$ & (8) \\
\hline \multirow[t]{6}{*}{ HIV infection } & Increased levels of $\mathrm{V} \delta 1 \mathrm{~T}$ cells & - & - & (58) \\
\hline & $\begin{array}{l}\text { Co-expression of IFN- } \gamma \text { and IL-17 (defense } \\
\text { against opportunistic infections), CD27 (memory } \\
\text { phenotype), CCR7 (homing), and CD161 } \\
\text { (transendothelial migration) }\end{array}$ & - & - & (59) \\
\hline & $\begin{array}{l}\text { Cytotoxicity against HIV-infected CD4+ } \mathrm{T} \text { cells } \\
\text { through NKG2C triggering }\end{array}$ & - & - & (60) \\
\hline & $\begin{array}{l}\text { Production of CCL3, CCL4, and CCL5 and } \\
\text { suppression of HIV replication through NKp30 } \\
\text { engagement }\end{array}$ & - & - & $(61)$ \\
\hline & - & $\begin{array}{l}\text { Large production of IFN- } \gamma \text {, TNF- } \alpha \text {, and the } \\
\text { chemokines CCL4/CCL5: blockade of HIV } \\
\text { co-receptors, attraction of more V } \delta 2^{+} \mathrm{T} \text { cells } \\
\text { able to release additional chemokine blocking } \\
\text { HIV entry and kill infected cells through direct } \\
\text { cytotoxicity or ADCC }\end{array}$ & - & (62) \\
\hline & - & $\begin{array}{l}\text { Signaling through the CCR5-gp120 } \\
\text { interaction: depletion of V } \delta 2^{+} \mathrm{T} \text { cells }\end{array}$ & - & (63) \\
\hline $\begin{array}{l}\text { Bacterial } \\
\text { meningitis }\end{array}$ & - & $\begin{array}{l}\text { Detection of } \mathrm{IL}-17^{+} \mathrm{V} \gamma 9 \mathrm{~V} \delta 2^{+} \text {lymphocytes in } \\
\text { the peripheral blood and at the site of disease } \\
\text { (a phenotype reversed by anti-bacterial } \\
\text { therapy) }\end{array}$ & - & (14) \\
\hline $\begin{array}{l}\text { Mycobacterial } \\
\text { infection }\end{array}$ & - & $\begin{array}{l}\text { Control of mycobacteria replication through } \\
\text { granzyme A and TNF- } \alpha \text { (produced by } \\
\text { macrophages) }\end{array}$ & - & (64) \\
\hline Hepatitis C virus & $\begin{array}{l}\text { Expansion and activation of } \mathrm{V} \delta 1+\mathrm{T} \text { cells in the } \\
\text { liver } \\
\text { Production of IFN- } \gamma \text { after polyclonal activation } \\
\text { in vitro. Contribution to necroinflammatory liver } \\
\text { disease because of their compartmentalization }\end{array}$ & - & - & $(65,66)$ \\
\hline $\begin{array}{l}\text { Human Herpes } \\
\text { virus } 8\end{array}$ & $\begin{array}{l}\text { Expanded } \vee \delta 1^{+} \mathrm{T} \text { cell populations with reactivity } \\
\text { toward HHV8-infected cells in vitro }\end{array}$ & - & - & (67) \\
\hline
\end{tabular}

ADCC, antibody-dependent cellular cytotoxicity; CMV, cytomegalovirus; EPCR, endothelial protein C receptor; SCID, severe combined immunodeficiency.

infections. NKG2C was outlined as the major triggering receptor involved in the V81 T-cell-mediated cytotoxicity against $\mathrm{HIV}$-infected $\mathrm{CD}^{+} \mathrm{T}$ cells (60). The engagement of NKp30 on V81 T cells induces CCL3, CCL4, and CCL5 production and suppress HIV replication (61). Altogether, these results are consistent with an antiviral potential of the V $\delta 1 \mathrm{~T}$ cells, possibly compensating the impairment of the $\mathrm{CD}^{+}{ }^{+} \mathrm{T}$-cell function during HIV infection.
Thus, the identification of stress-induced self antigens as targets expressed by infected cells may lead to the development of new therapeutic tools in infectious diseases. However, $\gamma \delta$ T-cell-based therapy may give rise to an uncontrolled inflammation with unwanted tissue destruction. Therefore, exploiting the underlying mechanisms of $\gamma \delta$ T-cell functions in infections will permit the modulation of their immunopathological consequences and could be beneficial to target pathogen proliferation. 
TABLE 3 | Main features of human $\gamma \delta$ T-cell subsets in chronic inflammatory manifestations.

\begin{tabular}{|c|c|c|c|c|}
\hline \multirow[t]{2}{*}{ Pathology } & \multicolumn{3}{|c|}{ Human $\gamma \delta$ T-cell subset features } & \multirow[t]{2}{*}{ Reference } \\
\hline & $\mathbf{V} \delta 1^{+}$ & $\mathbf{V} \delta 2^{+}$ & $\begin{array}{l}\text { Other } \\
\left.\text { V } \delta 2^{-} \text {(non-V } \delta 1\right)\end{array}$ & \\
\hline Myositis & - & $\begin{array}{l}\text { Recognition of AA-RS (also targeted by anti-Jo- } 1 \text { autoantibodies) by a } \\
\text { specific clone of } \mathrm{V} \gamma 1.3 \mathrm{~V} \delta 2^{-} \text {TCR (link between } \gamma \delta \mathrm{T} \text { and B cells) }\end{array}$ & - & $(77)$ \\
\hline Psoriasis & - & $\begin{array}{l}\text { Biomarkers for psoriasis, homing to the skin, production of pro- } \\
\text { inflammatory cytokines (IFN- } \gamma, \mathrm{TNF}-\alpha \text {, and IL-17A), induction of } \\
\text { immune cell recruitment from the circulation, release of growth factors } \\
\text { and tissue remodeling }\end{array}$ & - & $(78)$ \\
\hline Rheumatoid arthritis & - & $\begin{array}{l}\text { Antigen presentation capacity of effector-memory } \vee \gamma 9 \vee \delta 2^{+} T \text { cell } \\
\text { stimulated with IPP to CD4 } 4^{+} T \text { cells, secretion of pro-inflammatory } \\
\text { cytokines (IFN- } \gamma \text { and IL-17), disease progression }\end{array}$ & - & (79) \\
\hline $\begin{array}{l}\text { Systemic lupus } \\
\text { erythematosus }\end{array}$ & $\begin{array}{l}\text { Decrease of CD27+CD25 }{ }^{\text {high FoxP3 }}+ \\
\text { immunoregulatory } V \delta 1^{+} \mathrm{T} \text { cells }\end{array}$ & - & - & (80) \\
\hline
\end{tabular}

AA-RS, aminoacyl-histidyl-tRNA synthetase; IPP, isopentenyl pyrophosphate.

\section{$\gamma \delta \mathrm{T}$-Cell Subsets in Autoimmune and Other Chronic Inflammatory Diseases}

$\gamma \delta \mathrm{T}$ cells were also reported to play a key role in various chronic inflammatory pathologies (Table 3). For instance, in a rare variant of myositis, referred to as $\gamma \delta$ T-cell-mediated myositis, muscle fibers are attacked by CD8-negative $\mathrm{T}$ cells expressing the $\gamma \delta$-TCR. A V $\gamma 1.3 \mathrm{~V} \delta 2$ TCR clone (M88) was able to recognize the aminoacyl-histidyl-tRNA synthetase, an antigen also targeted by autoantibodies (77), suggesting a link between $\gamma \delta$ T cells and antibody-dependent response in autoimmune myositis.

In rheumatoid arthritis, stimulation of effector-memory V $\gamma 9 \mathrm{~V} \delta 2 \mathrm{~T}$ cell with isopentenyl pyrophosphate induces cell surface HLA-DR and co-stimulatory molecule expression and IFN- $\gamma$ and IL-17 secretion. This consequently activated antigen presentation to $\mathrm{CD}^{+} \mathrm{T}$ cells, sustained $\mathrm{T}$ cell activation, and aggravated the disease (79).

A subset of $\mathrm{CD} 27^{+} \mathrm{CD} 25^{\text {high }} \mathrm{V} \delta 1 \mathrm{~T}$ cells, expressing FoxP3 similarly to regulatory $\mathrm{CD} 4^{+} \mathrm{T}$ cells, was reported in patients with systemic lupus erythematosus (SLE). Their immunoregulatory activity is mainly cell-to-cell contact dependent. Unfortunately, this population is decreased in the blood of SLE patients, which could be important for the understanding of the pathogenesis of this disease (80).

In psoriasis patients, a homing/redistribution of $\mathrm{V} \gamma 9 \mathrm{~V} \delta 2$ $\mathrm{T}$ cells from blood to skin was observed. These cells produced an array of pro-inflammatory cytokines, such as IFN- $\gamma$, TNF- $\alpha$, and IL-17A, which induced the recruitment of blood immune cells, the release of growth factors, and the tissue remodeling. A psoriasis-targeted therapy could normalize the decreased numbers of circulating $\mathrm{V} \gamma 9 \mathrm{~V} \delta 2 \mathrm{~T}$ cells indicating that they represent an important biomarker (78). Of note, skin- $\gamma \delta \mathrm{T}$ cells were reported to play an important role in wound healing (81).

Given that $\gamma \delta \mathrm{T}$ cells could influence the pathogenesis of chronic inflammatory diseases, these cells will require a balance between their need for inflammatory mediators to function normally and a negative regulation of their unfavorable impact of the chronic inflammation (82). Therefore, additional studies should be carried out on human $\gamma \delta$ T-cell subsets to develop personalized $\gamma \delta$ T-cell-based therapies.

\section{CONCLUSION AND PERSPECTIVES}

These studies give us more insights about the relative contribution of V $\delta 1$ and V $\delta 2 \mathrm{~T}$ cells, as well as the mechanisms that could be targeted in order to develop efficient $\gamma \delta \mathrm{T}$-cell-based therapies. However, more extensive investigation is required to better evaluate the impact of these cells, i.e., their effector function, the subset plasticity and cell lineage. Furthermore, a deeper characterization of $\gamma \delta$ T-cell subsets in human is required given that most studies are conducted in mice. This will ultimately permit the manipulation of a specific subset according to a particular microenvironment. It is also important to understand how the novel therapies (e.g., ICP blockade) modulate $\gamma \delta$ T-cell function. Finally, one may speculate that $\gamma \delta$ T-cell subset-targeting could be beneficial to enhance or inhibit the outcome of adaptive immune responses against cancer, pathogens, or autoantigens, given their involvement in the regulation of other immune cell function.

\section{AUTHOR CONTRIBUTIONS}

ML wrote/revised the paper. JD-M and M-CD-N revised the paper.

\section{ACKNOWLEDGMENTS}

We thank all members of the Laboratory "Cancer, Immune control and Escape" at the UMRS1138 INSERM, Cordeliers Research Center, Paris, France.

\section{FUNDING}

This work was supported by Institut National de la Santé et de la Recherche Médicale (INSERM), University Paris Descartes (Sorbonne Paris Cité), University Pierre et Marie Curie (Sorbonne University), the Labex Immuno-Oncology (LAXE62_9UMS872), and the Institut National du Cancer (INCa-PLBio 2014-2017 GDSTRESS). 


\section{REFERENCES}

1. Bonneville M, O'Brien RL, Born WK. Gammadelta T cell effector functions: a blend of innate programming and acquired plasticity. Nat Rev Immunol (2010) 10(7):467-78. doi:10.1038/nri2781

2. Vantourout P, Hayday A. Six-of-the-best: unique contributions of $\gamma \delta \mathrm{T}$ cells to immunology. Nat Rev Immunol (2013) 13(2):88-100. doi:10.1038/ nri3384

3. Constant P, Davodeau F, Peyrat MA, Poquet Y, Puzo G, Bonneville M, et al. Stimulation of human gamma delta $\mathrm{T}$ cells by nonpeptidic mycobacterial ligands. Science (1994) 264(5156):267-70. doi:10.1126/science.8146660

4. Wrobel P, Shojaei H, Schittek B, Gieseler F, Wollenberg B, Kalthoff H, et al. Lysis of a broad range of epithelial tumour cells by human gamma delta T cells: involvement of NKG2D ligands and T-cell receptor- versus NKG2D-dependent recognition. Scand J Immunol (2007) 66(2-3):320-8. doi:10.1111/j.1365-3083.2007.01963.x

5. Todaro M, D’Asaro M, Caccamo N, Iovino F, Francipane MG, Meraviglia $\mathrm{S}$, et al. Efficient killing of human colon cancer stem cells by gammadelta T lymphocytes. J Immunol (2009) 182(11):7287-96. doi:10.4049/ jimmunol.0804288

6. Spada FM, Grant EP, Peters PJ, Sugita M, Melián A, Leslie DS, et al. Selfrecognition of CD1 by gamma/delta T cells: implications for innate immunity. J Exp Med (2000) 191(6):937-48. doi:10.1084/jem.191.6.937

7. Costa G, Loizon S, Guenot M, Mocan I, Halary F, de Saint-Basile G, et al. Control of Plasmodium falciparum erythrocytic cycle: $\gamma \delta$ T cells target the red blood cell-invasive merozoites. Blood (2011) 118(26):6952-62. doi:10.1182/ blood-2011-08-376111

8. Couzi L, Pitard V, Sicard X, Garrigue I, Hawchar O, Merville P, et al. Antibody-dependent anti-cytomegalovirus activity of human $\gamma \delta \mathrm{T}$ cells expressing CD16 (FcyRIIIa). Blood (2012) 119(6):1418-27. doi:10.1182/ blood-2011-06-363655

9. Silva-Santos B, Serre K, Norell H. $\gamma \delta$ T cells in cancer. Nat Rev Immunol (2015) 15(11):683-91. doi:10.1038/nri3904

10. Moens E, Brouwer M, Dimova T, Goldman M, Willems F, Vermijlen D. IL-23R and TCR signaling drives the generation of neonatal Vgamma9Vdelta2 T cells expressing high levels of cytotoxic mediators and producing IFN-gamma and IL-17. J Leukoc Biol (2011) 89(5):743-52. doi:10.1189/jlb.0910501

11. Ribot JC, Ribeiro ST, Correia DV, Sousa AE, Silva-Santos B. Human $\gamma \delta$ thymocytes are functionally immature and differentiate into cytotoxic type 1 effector T cells upon IL-2/IL-15 signaling. J Immunol (2014) 192(5):2237-43. doi:10.4049/jimmunol.1303119

12. Michel M-L, Pang DJ, Haque SF, Potocnik AJ, Pennington DJ, Hayday AC. Interleukin 7 (IL-7) selectively promotes mouse and human IL-17-producing $\gamma \delta$ cells. Proc Natl Acad Sci U S A (2012) 109(43):17549-54. doi:10.1073/ pnas. 1204327109

13. Ness-Schwickerath KJ, Jin C, Morita CT. Cytokine requirements for the differentiation and expansion of IL-17A- and IL-22-producing human Vgamma2Vdelta2 T cells. J Immunol (2010) 184(12):7268-80. doi:10.4049/ jimmunol.1000600

14. Caccamo N, La Mendola C, Orlando V, Meraviglia S, Todaro M, Stassi G, et al. Differentiation, phenotype, and function of interleukin-17-produc-

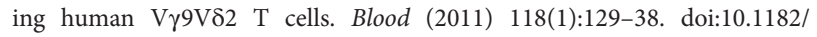
blood-2011-01-331298

15. Wu P, Wu D, Ni C, Ye J, Chen W, Hu G, et al. $\gamma \delta T 17$ cells promote the accumulation and expansion of myeloid-derived suppressor cells in human colorectal cancer. Immunity (2014) 40(5):785-800. doi:10.1016/j. immuni.2014.03.013

16. Brandes M, Willimann K, Moser B. Professional antigen-presentation function by human gammadelta T cells. Science (2005) 309(5732):264-8. doi:10.1126/science.1110267

17. Brandes M, Willimann K, Bioley G, Lévy N, Eberl M, Luo M, et al. Crosspresenting human gammadelta T cells induce robust CD8+ alphabeta T cell responses. Proc Natl Acad Sci U S A (2009) 106(7):2307-12. doi:10.1073/ pnas.0810059106

18. Meuter S, Eberl M, Moser B. Prolonged antigen survival and cytosolic export in cross-presenting human gammadelta T cells. Proc Natl Acad Sci U S A (2010) 107(19):8730-5. doi:10.1073/pnas.1002769107

19. Saveanu L, Carroll O, Weimershaus M, Guermonprez P, Firat E, Lindo V, et al. IRAP identifies an endosomal compartment required for $\mathrm{MHC}$ class I cross-presentation. Science (2009) 325(5937):213-7. doi:10.1126/ science. 1172845

20. Muto M, Baghdadi M, Maekawa R, Wada H, Seino K. Myeloid molecular characteristics of human $\gamma \delta \mathrm{T}$ cells support their acquisition of tumor antigen-presenting capacity. Cancer Immunol Immunother (2015) 64(8):941-9. doi:10.1007/s00262-015-1700-x

21. Leslie DS, Vincent MS, Spada FM, Das H, Sugita M, Morita CT, et al. CD1mediated gamma/delta T cell maturation of dendritic cells. J Exp Med (2002) 196(12):1575-84. doi:10.1084/jem.20021515

22. Ismaili J, Olislagers V, Poupot R, Fournié JJ, Goldman M. Human gamma delta T cells induce dendritic cell maturation. Clin Immunol (2002) 103(3 Pt 1): 296-302. doi:10.1006/clim.2002.5218

23. Ribeiro ST. Five layers of receptor signaling in $\gamma \delta$ T-cell differentiation and activation. Front Immunol (2015) 6:15. doi:10.3389/fimmu.2015.00015

24. Rincon-Orozco B, Kunzmann V, Wrobel P, Kabelitz D, Steinle A, Herrmann T. Activation of $\mathrm{V}$ gamma 9V delta $2 \mathrm{~T}$ cells by NKG2D. J Immunol (2005) 175(4):2144-51. doi:10.4049/jimmunol.175.4.2144

25. Das H, Groh V, Kuijl C, Sugita M, Morita CT, Spies T, et al. MICA engagement by human Vgamma2Vdelta2 $\mathrm{T}$ cells enhances their antigen-dependent effector function. Immunity (2001) 15(1):83-93. doi:10.1016/ S1074-7613(01)00168-6

26. Correia DV, Fogli M, Hudspeth K, da Silva MG, Mavilio D, Silva-Santos B, et al. Differentiation of human peripheral blood V81+ T cells expressing the natural cytotoxicity receptor NKp30 for recognition of lymphoid leukemia cells. Blood (2011) 118(4):992-1001. doi:10.1182/blood-2011-02-339135

27. Toutirais O, Cabillic F, Le Friec G, Salot S, Loyer P, Le Gallo M, et al. DNAX accessory molecule-1 (CD226) promotes human hepatocellular carcinoma cell lysis by Vgamma9Vdelta2 T cells. Eur J Immunol (2009) 39(5):1361-8. doi:10.1002/eji.200838409

28. Gertner-Dardenne J, Castellano R, Mamessier E, Garbit S, Kochbati E, Etienne A, et al. Human V $\gamma 9 \mathrm{~V} \delta 2 \mathrm{~T}$ cells specifically recognize and kill acute myeloid leukemic blasts. J Immunol (2012) 188(9):4701-8. doi:10.4049/ jimmunol.1103710

29. Lafont V, Liautard J, Liautard JP, Favero J. Production of TNF-alpha by human $\mathrm{V}$ gamma $9 \mathrm{~V}$ delta $2 \mathrm{~T}$ cells via engagement of fc gamma RIIIA, the low affinity type 3 receptor for the Fc portion of IgG, expressed upon TCR activation by nonpeptidic antigen. JImmunol (2001) 166(12):7190-9. doi:10.4049/ jimmunol.166.12.7190

30. Braza MS, Klein B, Fiol G, Rossi JF. $\gamma \delta$ T-cell killing of primary follicular lymphoma cells is dramatically potentiated by GA101, a type II glycoengineered anti-CD20 monoclonal antibody. Haematologica (2011) 96(3):400-7. doi:10.3324/haematol.2010.029520

31. Capietto AH, Martinet L, Fournié JJ. Stimulated $\gamma \delta \mathrm{T}$ cells increase the in vivo efficacy of trastuzumab in HER-2+ breast cancer. J Immunol (2011) 187(2):1031-8. doi:10.4049/jimmunol.1100681

32. DeBarros A, Chaves-Ferreira M, d'Orey F, Ribot JC, Silva-Santos B. CD70-CD27 interactions provide survival and proliferative signals that regulate $\mathrm{T}$ cell receptor-driven activation of human $\gamma \delta$ peripheral blood lymphocytes. Eur J Immunol (2011) 41(1):195-201. doi:10.1002/eji.201040905

33. Maniar A, Zhang X, Lin W, Gastman BR, Pauza CD, Strome SE, et al. Human gammadelta $\mathrm{T}$ lymphocytes induce robust $\mathrm{NK}$ cell-mediated antitumor cytotoxicity through CD137 engagement. Blood (2010) 116(10):1726-33. doi:10.1182/blood-2009-07-234211

34. Dolstra H, Fredrix H, van der Meer A, de Witte T, Figdor C, van de Wiel-van Kemenade E. TCR gamma delta cytotoxic T lymphocytes expressing the killer cell-inhibitory receptor p58.2 (CD158b) selectively lyse acute myeloid leukemia cells. Bone Marrow Transplant (2001) 27(10):1087-93. doi:10.1038/ sj.bmt. 1703043

35. Lesport E, Baudhuin J, Sousa S, LeMaoult J, Zamborlini A, Rouas-Freiss N, et al. Inhibition of human gamma delta [corrected] T-cell antitumoral activity through HLA-G: implications for immunotherapy of cancer. Cell Mol Life Sci (2011) 68(20):3385-99. doi:10.1007/s00018-011-0632-7

36. Gertner-Dardenne J, Fauriat C, Orlanducci F, Thibult ML, Pastor S, Fitzgibbon J, et al. The co-receptor BTLA negatively regulates human V $\gamma 9 \mathrm{~V} \delta 2$ T-cell proliferation: a potential way of immune escape for lymphoma cells. Blood (2013) 122(6):922-31. doi:10.1182/blood-2012-11-464685

37. Iwasaki M, Tanaka Y, Kobayashi H, Murata-Hirai K, Miyabe H, Sugie T, et al. Expression and function of PD-1 in human $\gamma \delta$ T cells that recognize phosphoantigens. Eur J Immunol (2011) 41(2):345-55. doi:10.1002/eji.201040959 
38. Gentles AJ, Newman AM, Liu CL, Bratman SV, Feng W, Kim D, et al. The prognostic landscape of genes and infiltrating immune cells across human cancers. Nat Med (2015) 21(8):938-45. doi:10.1038/nm.3909

39. Kabelitz D, Wesch D. Features and functions of gamma delta T lymphocytes: focus on chemokines and their receptors. Crit Rev Immunol (2003) 23(5-6):339-70. doi:10.1615/CritRevImmunol.v23.i56.10

40. Lança T, Costa MF, Gonçalves-Sousa N, Rei M, Grosso AR, Penido C, et al. Protective role of the inflammatory CCR2/CCL2 chemokine pathway through recruitment of type 1 cytotoxic $\gamma \delta \mathrm{T}$ lymphocytes to tumor beds. J Immunol (2013) 190(12):6673-80. doi:10.4049/jimmunol.1300434

41. Thomas ML, Badwe RA, Deshpande RK, Samant UC, Chiplunkar SV. Role of adhesion molecules in recruitment of Vdeltal $\mathrm{T}$ cells from the peripheral blood to the tumor tissue of esophageal cancer patients. Cancer Immunol Immunother (2001) 50(4):218-25. doi:10.1007/s002620100190

42. Zocchi MR, Ferrarini M, Rugarli C. Selective lysis of the autologous tumor by delta TCS1+ gamma/delta+ tumor-infiltrating lymphocytes from human lung carcinomas. Eur J Immunol (1990) 20(12):2685-9. doi:10.1002/ eji.1830201224

43. Mattarollo SR, Kenna T, Nieda M, Nicol AJ. Chemotherapy and zoledronate sensitize solid tumour cells to Vgamma9Vdelta2 $\mathrm{T}$ cell cytotoxicity. Cancer Immunol Immunother (2007) 56(8):1285-97. doi:10.1007/ s00262-007-0279-2

44. Fisher JP, Heuijerjans J, Yan M, Gustafsson K, Anderson J. $\gamma \delta$ T cells for cancer immunotherapy: a systematic review of clinical trials. Oncoimmunology (2014) 3(1):e27572. doi:10.4161/onci.27572

45. Cordova A, Toia F, La Mendola C, Orlando V, Meraviglia S, Rinaldi G, et al. Characterization of human $\gamma \delta \mathrm{T}$ lymphocytes infiltrating primary malignant melanomas. PLoS One (2012) 7(11):e49878. doi:10.1371/journal. pone.0049878

46. Siegers GM, Lamb LS Jr. Cytotoxic and regulatory properties of circulating $\mathrm{V} \delta 1+\gamma \delta \mathrm{T}$ cells: a new player on the cell therapy field? Mol Ther (2014) 22(8):1416-22. doi:10.1038/mt.2014.104

47. Peng G, Wang HY, Peng W, Kiniwa Y, Seo KH, Wang RF. Tumor-infiltrating gammadelta $\mathrm{T}$ cells suppress $\mathrm{T}$ and dendritic cell function via mechanisms controlled by a unique toll-like receptor signaling pathway. Immunity (2007) 27(2):334-48. doi:10.1016/j.immuni.2007.05.020

48. D’Asaro M, La Mendola C, Di Liberto D, Orlando V, Todaro M, Spina M, et al. $\mathrm{V}$ gamma $9 \mathrm{~V}$ delta $2 \mathrm{~T}$ lymphocytes efficiently recognize and kill zoledronate-sensitized, imatinib-sensitive, and imatinib-resistant chronic myelogenous leukemia cells. J Immunol (2010) 184(6):3260-8. doi:10.4049/ jimmunol.0903454

49. Lança T, Correia DV, Moita CF, Raquel H, Neves-Costa A, Ferreira C, et al. The MHC class Ib protein ULBP1 is a nonredundant determinant of leukemia/lymphoma susceptibility to gammadelta T-cell cytotoxicity. Blood (2010) 115(12):2407-11. doi:10.1182/blood-2009-08-237123

50. Couzi L, Levaillant Y, Jamai A, Pitard V, Lassalle R, Martin K, et al. Cytomegalovirus-induced gammadelta $\mathrm{T}$ cells associate with reduced cancer risk after kidney transplantation. J Am Soc Nephrol (2010) 21(1):181-8. doi:10.1681/ASN.2008101072

51. Lamb LS, Henslee-Downey PJ, Parrish RS, Godder K, Thompson J, Lee C, et al. Increased frequency of TCR gamma delta $+\mathrm{T}$ cells in disease-free survivors following $\mathrm{T}$ cell-depleted, partially mismatched, related donor bone marrow transplantation for leukemia. J Hematother (1996) 5(5):503-9. doi:10.1089/ scd.1.1996.5.503

52. Ma C, Zhang Q, Ye J, Wang F, Zhang Y, Wevers E, et al. Tumor-infiltrating $\gamma \delta$ $\mathrm{T}$ lymphocytes predict clinical outcome in human breast cancer. J Immunol (2012) 189(10):5029-36. doi:10.4049/jimmunol.1201892

53. Champagne E. $\gamma \delta \mathrm{T}$ cell receptor ligands and modes of antigen recognition. Arch Immunol Ther Exp (2011) 59(2):117-37. doi:10.1007/ s00005-011-0118-1

54. Tyler CJ, Doherty DG, Moser B, Eberl M. Human V $\gamma 9 / \mathrm{V} \delta 2$ T cells: innate adaptors of the immune system. Cell Immunol (2015) 296(1):10-21. doi:10.1016/ j.cellimm.2015.01.008

55. Halary F, Pitard V, Dlubek D, Krzysiek R, de la Salle H, Merville P, et al. Shared reactivity of $\mathrm{V}\{$ delta\}2(neg) \{gamma\}\{delta\} $\mathrm{T}$ cells against cytomegalovirus-infected cells and tumor intestinal epithelial cells. J Exp Med (2005) 201(10):1567-78. doi:10.1084/jem.20041851

56. Willcox CR, Pitard V, Netzer S, Couzi L, Salim M, Silberzahn T, et al. Cytomegalovirus and tumor stress surveillance by binding of a human $\gamma \delta$
T cell antigen receptor to endothelial protein C receptor. Nat Immunol (2012) 13(9):872-9. doi:10.1038/ni.2394

57. Ehl S, Schwarz K, Enders A, Duffner U, Pannicke U, Kühr J, et al. A variant of SCID with specific immune responses and predominance of gamma delta T cells. J Clin Invest (2005) 115(11):3140-8. doi:10.1172/JCI25221

58. De Paoli P, Gennari D, Martelli P, Basaglia G, Crovatto M, Battistin S, et al. A subset of gamma delta lymphocytes is increased during HIV-1 infection. Clin Exp Immunol (1991) 83(2):187-91. doi:10.1111/j.1365-2249.1991. tb05612.x

59. Fenoglio D, Poggi A, Catellani S, Battaglia F, Ferrera A, Setti M, et al. Vdelta1 T lymphocytes producing IFN-gamma and IL-17 are expanded in HIV-1-infected patients and respond to Candida albicans. Blood (2009) 113(26):6611-8. doi:10.1182/blood-2009-01-198028

60. Fausther-Bovendo H, Wauquier N, Cherfils-Vicini J, Cremer I, Debré P, Vieillard $\mathrm{V}$, et al. NKG2C is a major triggering receptor involved in the V[delta]1 T cell-mediated cytotoxicity against HIV-infected CD4 T cells. AIDS (2008) 22(2):217-26. doi:10.1097/QAD.0b013e3282f46e7c

61. Hudspeth K, Fogli M, Correia DV, Mikulak J, Roberto A, Della Bella S, et al. Engagement of NKp30 on V81 T cells induces the production of CCL3, CCL4, and CCL5 and suppresses HIV-1 replication. Blood (2012) 119(17):4013-6. doi:10.1182/blood-2011-11-390153

62. Poonia B, Pauza CD. Gamma delta T cells from HIV+ donors can be expanded in vitro by zoledronate/interleukin-2 to become cytotoxic effectors for antibody-dependent cellular cytotoxicity. Cytotherapy (2012) 14(2):173-81. d oi:10.3109/14653249.2011.623693

63. Li H, Pauza CD. HIV envelope-mediated, CCR5/ $\alpha 4 \beta 7$-dependent killing of CD4-negative $\gamma \delta \mathrm{T}$ cells which are lost during progression to AIDS. Blood (2011) 118(22):5824-31. doi:10.1182/blood-2011-05-356535

64. Spencer CT, Abate G, Sakala IG, Xia M, Truscott SM, Eickhoff CS, et al. Granzyme A produced by $\gamma(9) \delta(2) \mathrm{T}$ cells induces human macrophages to inhibit growth of an intracellular pathogen. PLoS Pathog (2013) 9(1):e1003119. doi:10.1371/journal.ppat.1003119

65. Agrati C, D’Offizi G, Narciso P, Abrignani S, Ippolito G, Colizzi V, et al. Vdelta1 T lymphocytes expressing a Th1 phenotype are the major gammadelta T cell subset infiltrating the liver of HCV-infected persons. Mol Med (2001) 7(1):11-9.

66. Agrati C, D’Offizi G, Narciso P, Selva C, Pucillo LP, Ippolito G, et al. Gammadelta $\mathrm{T}$ cell activation by chronic HIV infection may contribute to intrahepatic vdeltal compartmentalization and hepatitis $C$ virus disease progression independent of highly active antiretroviral therapy. AIDS Res Hum Retroviruses (2001) 17(14):1357-63. doi:10.1089/08892220152596614

67. Barcy S, De Rosa SC, Vieira J, Diem K, Ikoma M, Casper C, et al. Gamma delta+ $\mathrm{T}$ cells involvement in viral immune control of chronic human herpesvirus 8 infection. J Immunol (2008) 180(5):3417-25. doi:10.4049/ jimmunol.180.5.3417

68. Déchanet J, Merville P, Lim A, Retière C, Pitard V, Lafarge X, et al. Implication of gammadelta $\mathrm{T}$ cells in the human immune response to cytomegalovirus. J Clin Invest (1999) 103(10):1437-49. doi:10.1172/JCI5409

69. Vermijlen D, Brouwer M, Donner C, Liesnard C, Tackoen M, Van Rysselberge M, et al. Human cytomegalovirus elicits fetal gammadelta T cell responses in utero. JExp Med (2010) 207(4):807-21. doi:10.1084/ jem.20090348

70. Knight A, Madrigal AJ, Grace S, Sivakumaran J, Kottaridis P, Mackinnon S, et al. The role of $\mathrm{V} \delta 2$-negative $\gamma \delta \mathrm{T}$ cells during cytomegalovirus reactivation in recipients of allogeneic stem cell transplantation. Blood (2010) 116(12):2164-72. doi:10.1182/blood-2010-01-255166

71. Autran B, Triebel F, Katlama C, Rozenbaum W, Hercend T, Debre P. T cell receptor gamma/delta+ lymphocyte subsets during HIV infection. Clin Exp Immunol (1989) 75(2):206-10.

72. Glatzel A, Wesch D, Schiemann F, Brandt E, Janssen O, Kabelitz D. Patterns of chemokine receptor expression on peripheral blood gamma delta $\mathrm{T}$ lymphocytes: strong expression of CCR5 is a selective feature of $\mathrm{V}$ delta $2 / \mathrm{V}$ gamma 9 gamma delta T cells. J Immunol (2002) 168(10):4920-9. doi:10.4049/ jimmunol.168.10.4920

73. Chen ZW, Letvin NL. V $\gamma 2$ V $82+T$ cells and anti-microbial immune responses. Microbes Infect (2003) 5(6):491-8. doi:10.1016/S1286-4579(03)00074-1

74. Boismenu R, Feng L, Xia YY, Chang JC, Havran WL. Chemokine expression by intraepithelial gamma delta $\mathrm{T}$ cells. Implications for the recruitment of inflammatory cells to damaged epithelia. J Immunol (1996) 157(3):985-92. 
75. Qin G, Liu Y, Zheng J, Ng IH, Xiang Z, Lam KT, et al. Type 1 responses of human V $\gamma 9 \mathrm{~V} \delta 2 \mathrm{~T}$ cells to influenza A viruses. J Virol (2011) 85(19):10109-16. doi:10.1128/JVI.05341-11

76. Poccia F, Battistini L, Cipriani B, Mancino G, Martini F, Gougeon ML, et al. Phosphoantigen-reactive Vgamma9Vdelta2 $\mathrm{T}$ lymphocytes suppress in vitro human immunodeficiency virus type 1 replication by cell-released antiviral factors including CC chemokines. J Infect Dis (1999) 180(3):858-61. doi:10.1086/314925

77. Bruder J, Siewert K, Obermeier B, Malotka J, Scheinert P, Kellermann J,et al. Target specificity of an autoreactive pathogenic human $\gamma \delta$-T cell receptor in myositis. J Biol Chem (2012) 287(25):20986-95. doi:10.1074/jbc.M112.356709

78. Laggner U, Di Meglio P, Perera GK, Hundhausen C, Lacy KE, Ali N, et al. Identification of a novel proinflammatory human skin-homing $\mathrm{V} \gamma 9 \mathrm{~V} \delta 2 \mathrm{~T}$ cell subset with a potential role in psoriasis. J Immunol (2011) 187(5):2783-93. doi:10.4049/jimmunol.1100804

79. Hu C, Qian L, Miao Y, Huang Q, Miao P, Wang P, et al. Antigen-presenting effects of effector memory V $\gamma 9 \mathrm{~V} \delta 2 \mathrm{~T}$ cells in rheumatoid arthritis. Cell Mol Immunol (2012) 9(3):245-54. doi:10.1038/cmi.2011.50

80. Li X, Kang N, Zhang X, Dong X, Wei W, Cui L, et al. Generation of human regulatory gammadelta $\mathrm{T}$ cells by TCRgammadelta stimulation in the presence of TGF-beta and their involvement in the pathogenesis of systemic lupus erythematosus. J Immunol (2011) 186(12):6693-700. doi:10.4049/ jimmunol.1002776

81. Toulon A, Breton L, Taylor KR, Tenenhaus M, Bhavsar D, Lanigan C, et al A role for human skin-resident T cells in wound healing. J Exp Med (2009) 206(4):743-50. doi:10.1084/jem.20081787

82. Fay NS, Larson EC, Jameson JM. Chronic inflammation and $\gamma \delta \mathrm{T}$ cells. Front Immunol (2016) 7:210. doi:10.3389/fimmu.2016.00210

Conflict of Interest Statement: The authors declare that the research was conducted in the absence of any commercial or financial relationships that could be construed as a potential conflict of interest.

Copyright ๔ 2017 Lawand, Déchanet-Merville and Dieu-Nosjean. This is an open-access article distributed under the terms of the Creative Commons Attribution License (CC BY). The use, distribution or reproduction in other forums is permitted, provided the original author(s) or licensor are credited and that the original publication in this journal is cited, in accordance with accepted academic practice. No use, distribution or reproduction is permitted which does not comply with these terms. 